\title{
“A Class Act: Constance Lytton and the political, literary and dramatic dynamics of suffrage prison writings"
}

'In years to come this story of compassion and chivalry will be told in the schools to children yet unborn,' declared Katherine Roberts in 1910, predicting that Lady Constance Lytton would become an inspirational figure for future generations. ${ }^{1}$ A militant suffragette, Constance Lytton had disguised herself as a working-class seamstress, Jane Warton, in order to expose the brutal treatment of less privileged suffragist prisoners. When she had previously been arrested in 1909 for stonethrowing, a congenital heart condition saw her confined to the hospital wing and exempted from all labour, alongside Mrs Brailsford, the wife of an M.P., while working-class suffragettes, Mary Leigh and Selina Martin, who had been arrested with them, were placed in the Third Division and subjected to force-feeding. Outraged by such unequal treatment, Lytton disguised herself as Jane Warton, a London seamstress, under which identity prison doctors failed to diagnose her heart condition and subjected her to force-feeding eight times before her rapidly declining health and suspicions of her true identity prompted her release. The publication in 1914 of Prisons and Prisoners: Some personal experiences. By Constance Lytton and Jane Warton, Spinster led a reviewer in the Christian Commonwealth to exclaim ecstatically that 'Constance Lytton is an incarnation of the Christ-spirit, if ever there was one. The story of her deeds - the motive that inspired them, the spirit in which she did them - is worthy of being enshrined in the Sacred Books of the race.'2 Christabel Pankhurst drew both on the language of religious sacrifice and on that of male stoicism and courage: 'No act more chivalrous can be imagined than Lady Constance Lytton's surrender of every advantage of her own for the sake of more defenceless women. The sacrifice of the brave Captain Oates, who went into the snow to die that his comrades might have the greater chance to live, brought tears to our eyes. But cannot the world - the world even of men - understand that Lady Constance Lytton's act was of the same, perhaps of yet finer quality! ${ }^{3}$

\footnotetext{
${ }^{1}$ Katherine Roberts, Pages from the diary of a militant suffragette (Letchworth: Garden City Press , 1910), 137

2 Christian Commonwealth, 11 March 1914, quoted in Constance Lytton, Prisons and Prisoners, Some Personal Experiences, ed. Jason Haslam (Broadview Editions: Peterborough, Ontario, 2008), Appendix D, 321.

${ }^{3}$ Christabel Pankhurst, “A Prisoner’s Book”, The Suffragette, 13 March 1914, quoted in ibid, 325.
} 
Lytton's story has not found a place in the school curriculum, while Captain Oates's name still survives as a synonym for heroic self-sacrifice, but Prisons and Prisoners has become established as a key suffrage text, one of the most prominent and important books in the rich field of suffrage narratives. ${ }^{4}$ This is partly due to the political significance of her masquerade and imprisonment, which were perfectly calculated to meet the needs of the militant suffrage cause at that time. As an act of cross-class solidarity, Lytton's self-sacrifice helped to bridge tensions between suffragists supporting enfranchisement on equal grounds for women and men, and those campaigning for universal adult suffrage, and to bring together the single-issue WSPU and organisations with a greater focus on workers' rights. By exposing the 'snobbish privilege' and hypocrisy that governed Constance Lytton's and Jane Warton's different treatments, Lytton also gave the lie to the authorities' claim to justice. ${ }^{5}$ Their reluctance to inflict force-feeding on a member of the aristocracy powerfully enforced the suffragettes' argument that force-feeding as not 'special medical treatment', but in reality a torture, designed to punish women and intimidate them into abandoning militant tactics. ${ }^{6}$ Lytton's carefully planned and strategically effective entrapment of the prison authorities also contradicted the implication that suffragettes were hysterical or mad and so fitted for a treatment otherwise reserved for the inmates of mental asylums. Deliberately acting on her own initiative, Lytton's self-sacrifice was ideal propaganda material, being freely made, not ordered by the leadership of WSPU, whose autocratic command structures and apparent indifference

\footnotetext{
${ }^{4}$ For recent studies of suffrage narratives concentrating centrally on Prisons and Prisoners see e.g. Laura E Nym Mayhall, “Creating the 'Suffrage Spirit': British Feminism and the historical imagination', Women's History Review 4:3 (1995); Caroline J. Howlett, 'Writing on the Body? Representation and Resistance in British Suffragette Accounts of Forcible Feeding', in Bodies of Writing, Bodies in Performance, ed. Thomas Foster, Carol Siegel, and Ellen E. Berry, Genders 23 (New York University Press: NY and London, 1996); Kabi Hartman, “'What made a suffragette': the new woman and the new (?) conversion narrative’ Women’s History Review, 12: 1 (2003), 35-50.

5 Prisons and Prisoners. Some Personal Experiences. By Constance Lytton and Jane Warton, Spinster (New York: George H. Doran, 1914), 162.

6 'Questions in the House', Votes for Women, 8 October 1909, 20. See also "Suffragist Women Prisoners”, Home Office Papers and Memoranda 1889-1910 (London, 1910), in Prisons and Prisoners, ed. Haslam, Appendix E.
} 
to the physical suffering of militant activists were increasingly drawing criticism from former supporters. ${ }^{7}$

Prisons and Prisoners was not just a valuable political intervention, an exemplary conversion narrative and a tale of remarkable courage and endurance, it was also a complex and unusually experimental literary text. In narrating her prison experiences and her masquerade as Jane Warton, Constance Lytton drew on a deep understanding of the relation between actor and role that was rooted in the particular dynamics of contemporary feminist and suffragist literature. Recent critics have called for a re-evaluation of modernism and the modernist canon in relation to women's writing and suffragist writings in particular, calling for a more expansive definition of modernist experimentation and its associated values. Lucy Delap and Maria DiCenzo, for example, have argued that it is important to differentiate between modernity and modernism, the former for many women being marked by increased rights and freedoms which helped to produce an optimism at odds with the anti-modern sentiments that characterised so many high modernist writings. ${ }^{8}$ Impersonality, apoliticisim, aesthetic detachment, and individualism - the values prized by modernists such as Eliot and Pound, ran contrary to core values celebrated in women's suffrage writings. Suffrage literature, as Sowon Park has noted, cuts across the theoretical divide between politically naive 'realist' writings and truly subversive 'modernist' literature. ${ }^{9}$ Urmila Seshagiri has similarly argued that we need to recognise the central role played by suffragist writings in early twentieth-century literary culture and the nuanced and intricate ways in which they interact with modernist techniques. ${ }^{10}$ Prisons and Prisoners is just such a text with the potential to expand definitions and understandings of modernist writing. A first-person narrative that also foregrounds the instability of the 'I', as Park has noted so many suffrage memoirs do, Prisons and Prisoners charts Constance Lytton’s journey from dutiful and conventional aristocratic daughter to economic and intellectual independence as a

\footnotetext{
7 See e.g., Teresa Billington-Greig, The Militant Suffrage Movement. Emancipation in a Hurry (London: Frank Palmer, 1911), 69-70, 74-5, and Cicely Hamilton, Life Errant (London: J. M. Dent \& Sons, 1935), 73, 68.

8 Lucy Delap and Maria DiCenzo, 'Transatlantic Print Culture: The Anglo-American Feminist Press and Emerging “Modernities”, in Transatlantic Print Culture, 1880-1940: Emerging Media, Emerging Modernisms, ed. Ann Ardis and Patrick Collier (Palgrave Macmillan: Basingstoke, 2008), 48-65.

${ }^{9}$ Sowon S. Park, “Political Activism and Women's Modernism”, The Cambridge Companion to Modernist Women Writers, Ed. Maren Tova Linett (CUP: Cambridge, 2010), 174-5.

10 Urmila Seshagiri, 'Making it New: Persephone Books and the Modernist Project', Modern Fiction Studies 59.2 (2013), 241-87.
} 
political activist, her identity underpinned by a sense of female solidarity and collective endeavour. ${ }^{11}$ While narrating an exemplary trajectory for a modern woman from social conformity to the breaking of class and gender expectations, Lytton's memoir is also a complex literary text, in which the narrative voice shifts unexpectedly from first to third person, and metaphor is used to strategically disconcerting effect. Her literary tactics are deployed to challenge established social structures and class hierarchies and the authorities resting upon them. At the heart of Prisons and Prisoners is Lytton's quiet, self-deprecating and determined voice, through which she reveals the disjunctions between women's first-hand experience and the structures and assumptions that condition their lives.

Lytton's literary techniques were also rooted in the common concern of suffrage writers and activists to communicate the suffering and endurance of women, especially after the commencement of the militant campaign in 1905, together with the truth of women's individual embodied experience, as most intimately communicated in first-person narratives. 'Spectacle' and 'performance' have become common terms at the centre of suffrage history and criticism, ever since the publication of Lisa Tickner's ground-breaking and brilliant The Spectacle of Women: Imagery of the Suffrage Campaign 1907-14 in 1987. 'Spectacle' applied not only to the art works, banners, posters, processions, platform oratory and militant violence of the suffrage campaign, but also the narration of women's pain in the cloistered spaces of prison cells; as Barbara Green has explained in her superb Spectacular Confessions: Autobiography, Performative Activism, and the Sites of Suffrage 19051938 (1997), suffrage memoirs and first-person reportage transformed private sufferings into public activism. 'Performative' and 'performance' are vital terms, but they can be used loosely as a catch-all term to refer to anything intended for a public audience of spectators, auditors or readers, without necessarily paying attention to the precise mechanisms of dramatic representation and the particularities of theatrical genre. Constance Lytton was impressively informed on suffrage theories and techniques - as she explained, her conversion was prefaced by detailed and extensive research, having “"read up” on the subject as I had never read in my life before', studying Votes for Women, attending meetings, talking with freed prisoners, and

\footnotetext{
11 Park, 'Political Activism', 181. For further discussion of 'voice' in relation to women's suffrage writing and literary cultures, see Mary Chapman, Making Noise, Making News: Suffrage Print Culture and U.S. Modernism (OUP: Oxford \& NY, 2014), Introduction.
} 
studying contemporary political tactics - and theatre was an intimate and integrated part of the campaign. ${ }^{12}$ Recognising Lytton's deployment of theatrical metaphors and techniques is vital to comprehending the sophistication and power of her writing and the particular dynamics of theatre's influence in suffrage activism.

Attention-grabbing visual images and effects were crucial in advertising and disseminating suffrage politics, but, as became apparent, without anchoring in context and in women's embodied experience, spectacle could be a double-edged weapon. As Rosemary Betterton has observed, not only has the male gaze necessarily problematized visual representations of women through a long history of sexualization and objectification, but isolated images are also open to reinterpretation, reframing and manipulation. ${ }^{13}$ So, for example, in May 1914 the Daily Mirror published a photographic montage of suffragettes, their faces contorted and distorted in apparent rage and hysteria; entitled 'The Suffragette Face: New Type Evolved by Militancy', the paper described the portraits as demonstrating the peculiar and unmistakable look of 'Fanaticism' that accompanied militancy. The photos were, however, carefully cropped, removing the police officers lifting women off their feet in tight holds or twisting their arms behind them; experiences of pain, surprise and fear could thus be reframed as mania. ${ }^{14}$ 'Spectacle' can signify pageant, extravaganza or display, but it can also imply sensationalism, self-advertising, attention-grabbing and inauthenticity. To fulfil its propagandist role in a campaign whose arguments were crucially rooted in the realities of women's economic, social and legal position, spectacle had to be married to embodied experience. Theatre, whose material is the living body of the actor, had the ultimate potential to unite the visual and the visceral.

Constance Lytton was extraordinarily adept at marrying spectacle and embodied experience in her writing. One of the most viscerally striking episodes in Prisons and Prisoners is her account of cutting the letter ' $\mathrm{V}$ ' into her chest in protest at her confinement in the hospital ward of Holloway prison and the denial of her repeated requests to be united with the women arrested and sentenced alongside her. As Lytton explains:

\footnotetext{
12 Prisons and Prisoners, 14.

13 Rosemary Betterton, An Intimate Distance: Women, Artists and the Body (Routledge: London, 1996), chap.1.

${ }^{14}$ Ibid, 67.
} 
I had decided to write the words 'Votes for Women' on my body, scratching it in my skin with a needle, beginning over the heart and ending it on my face. I proposed to show the first half of the inscription to the doctors, telling them that as I knew how much appearances were respected by officials, I thought it well to warn them that the last letter and a full stop would come upon my cheek, and be still quite fresh and visible on the day of my release. (64)

Lytton converts her body into political capital, turning the doctor's concern for social class and appearances against him. She also literalizes a widespread militant tactic that could be termed 'breaking the skin', disrupting the smooth surfaces of decorum and exchange: suffragettes interrupted meetings, slashed paintings, carved slogans into golf courses and broke windows. Lytton's account of the surprising toughness of her skin, the inadequacy of an ordinary sewing needle and her final use of a polished enamelled hairpin to cut through it, gives a painful physical immediacy to her symbolic act. When the letter is finally gouged into her recalcitrant skin,

I felt all a craftsman's satisfaction in my job. The $\mathrm{V}$ was very clearly and evenly printed in spite of the varying material of its background, a rib bone forming an awkward bump. As I pointed out to the doctor, it had been placed exactly over the heart, and visibly recorded the pulsation of that organ as clearly as a watch hand, so that he no longer need be put to the trouble of the stethoscope. (168)

Lytton's artistry is to make her body both a scandalous political spectacle and a physical reality, complete with recalcitrant tissues and a heartbeat visible even to prison doctors uninterested in taking her pulse before declaring her healthy or debilitated.

As Lady Constance Lytton's, her body was declared too frail to undertake cleaning duties of which she knew herself entirely capable (143); when Jane Warton became ill, however, after repeated force-feedings, a junior doctor 'stooped down and listened to my heart through the stethoscope for barely the space of a second - he could not have heard two beats - and exclaimed, "Oh ripping, splendid heart! You can go on with her"' (275) Neatly reversing the anti-feminist formula that a woman’s reason is inescapably subject to the vagaries of her hormonal body, Constance Lytton showed how her body was constructed and reconstructed according to the convenience and vagaries of male minds. ${ }^{15}$ Her self-wounding was designed to

\footnotetext{
15 For an extreme expression of anti-suffragist medical opinion on the subjection of women's reason to their biological and hormonal fluctuations, see Sir Almroth E. Wright, 'On Militant Hysteria', Times, 28 March, 1912, and his expanded treatise, The Unexpurgated Case against Woman Suffrage (1913).
} 
transform her body into propagandist spectacle, but it also served to emphasize her body's physical reality, its tenaciously tough flesh and its inner workings - a reality ignored by the prison doctors' class-biased perceptions.

Lytton's unusual use of metaphor similarly worked to unsettle the frameworks and value systems that judged and ordered women's lives and measured their worth. Often quietly comic, her visual metaphors and analogies reflect her particular class perspective and individual experience, and through a subtle use of disjunction they highlight and dislocate assumed class hierarchies. So she comments of the wardresses in prison: 'They held themselves very upright, and their general bearing brought to my mind certain types of the chaperon's bench at Court balls.' (73) When a wardress records her personal appearance on her admission to Holloway, Lytton describes 'a comic moment when the wardress looked up with her head on one side, as any portrait painter might do, to investigate the colour of one's hair and eyes.' (75) The allusion to her upper-class frame of reference here delivers a vivid sense of the posture, manner and appearance of the wardresses, while the incongruity of the aligned images derives a sly humour from the social distance between the two contexts. She does not merge the two social worlds, but her simile breaks down the assumed remoteness and conventional hierarchical relation between them, simultaneously measuring class likeness and difference. Lytton's use of metaphor implicitly questions class positions and the structures of authority, power and economics that determine their value in the world.

Lytton is also particularly careful not to use metaphor to erase distinctions or obscure the particularities of agency - a care that is more apparent when compared with the looser use of metaphor in, for example, Gertrude Colmore's fictional treatment of Lytton's prison experiences in her novel Suffragette Sally (1911). Colmore, by contrast, repeatedly uses metaphorical language to blur and evade issues of responsibility. So, for example, Lady Geraldine Hill (Colmore’s fictional version of Constance Lytton) uses the image of the incoming tide to answer her friend Edith's doubts about the justification for militant tactics:

'Have you ever watched the tide come in?' asked Geraldine. 'When it's far out, a long way from the shore, it ripples along gently, as the woman's movement did for fifty years; a very lady-like tide; and nobody heeds it nobody on the shore, I mean. But when it gets to the beach, and the slope is steep and there are stones and rocks which stem the force, the irresistible force 
of it, then the smooth waves change to breakers, and the nearer it comes to its destined goal, the fiercer the conflict.'

[....] 'Do you think then that nothing is to be done without aggression?'

'Almost, I am inclined to think so. But what makes the thing that is called aggression? Not the steady unfolding of a new phase of the world's development - and all the movements of progress are just that - but the opposition which is offered to the unfolding. It is the rocks which make the breakers, it is the rocks round which the in-coming tide eddies and swirls. You cannot blame the sea, which inevitably follows the law laid down for it.'

'The rocks make the breakers, you say. Yes - perhaps,' said the girl slowly; 'but it is the waves that are broken.'

'Individual waves; but the tide comes in. And individual women have been and will be broken: but woman will reach her destined place. ${ }^{16}$

By replacing command and decision structures, individual women, and specific actions and events with the undifferentiated mass of seawater, drawn forward by vast irresistible forces, Colmore evades all the particularities of responsibility, motivation, political expediency and propagandist strategy. The metaphor of the tide is then redeployed repeatedly throughout the novel, to frame women interrupting political meetings, rushing the House of Commons and imagining the future progress of the women’s movement. ${ }^{17}$ Similarly, the red light of sunset is repeatedly deployed as a metaphorical accompaniment to moments of violence, rendering it difficult to identify individual acts or to trace specific responsibility in flights of Dickensian oratory, as in the following comment on the aftermath of 'Black Friday':

About the towers of Westminster the sky was red like blood. There were touches of red, very like to blood, on the pavement; stains, very like to blood, on the bodies of women; something, very like to blood, on the heads of men who were not in the crowd that day. (282) ${ }^{18}$

Blood is there and not there, eliding the specifics of individual bodies and leaving the focus deliberately blurred. Colmore exploits the indeterminacy of metaphor to invoke notions of destiny and the workings of depersonalised forces, and thus obscures vital issues of responsibility and physical and political agency.

Lytton's similes, by contrast, paint a precise picture, her visual analogies bringing appearances more sharply into focus, while engaging with and challenging

\footnotetext{
${ }^{16}$ Gertrude Colmore, Suffragette Sally, ed. Alison Lee (Broadview: Peterborough, Ontario, 2008. First published 1911 by Stanley Paul and Co., London), 73-4.

${ }^{17}$ See e.g. ibid, 82, 119, 170.

${ }^{18}$ See also e.g. 83, 170, 278.
} 
the conventional values and hierarchies associated with them. The panoptic structure of Holloway Prison is distinctly drawn in her description of the prison yard:

The prison from here looks like a great hive of human creeping things impelled to their joyless labours and unwilling seclusion by some hidden force, the very reverse of natural, and which has in it no element of organic life, cohesion, or self-sufficing reason. A hive of hideous purpose from which flows back day by day into the surrounding city a stream of evil honey, blackened in the making and poisonous in result. The high central tower seemed to me a jam pot, indicative of the foul preserve that seethed within this factory for potting human souls. (188)

The diminutive status of the prisoners under the watchful height of the tower is neatly conveyed by the natural metaphor, a metaphor that simultaneously serves to underline the converse purposes of the human structure. Reversing established theories of the prison as an efficient machine for surveillance, discipline and rehabilitation, Lytton's imagery transforms it into a factory for corruption and debasement, dehumanizing its inhabitants and 'potting' their souls - an image of containment, diminution and death. ${ }^{19}$

By drawing parallels between two different scenes, Lytton superimposes them so that both similarities and distinctions are clear. Watching the daily pacing in the prison yard of 'the debtor, the drunkard, the thief, the hooligan, the prostitute, the child murderer' (134), her mind’s eye conjures up

a counter-procession of women of this leisured class, herded as I have so often seen them at ball-rooms and parties, enduring the labours, the penalties, of futile, superficial, sordidly useless lives, quarrelling in their marriage market, revelling in their petty triumphs, concerned continually with money, yielding all opinion to social exigencies, grovelling to those they consider above them, despising and crushing those they think beneath them.... And immediately the procession of Holloway yard seemed human, dignified, almost enviable by the side of that other. It is these leisured women the women's movement has hitherto cast aside. They are the dross, the dead fruit. (135-6)

Women circling the exercise yard fuse momentarily with women circling a ballroom, both under the watchful eye of chaperons and both caught within social systems that deny them dignity, though it is the leisured women whose debasement is most profound. It is the upper-class women who not only collude willingly in a system of laws and conventions that limits and damages the lives of poorer women, but who

19 See Michel Foucault, Discipline and Punish: The Birth of the Prison, trans from the French by Alan Sheridan (Penguin: London, 1991), Parts 3 \& 4 for the classic study of prison as panopticon. 
even make an ideal of the 'maiming subserviency' of their own existence. (40) Lytton's visual images invite two sets of bodies to inhabit the same skins. The bodily conjunctions and mirrorings challenge the economic and social distances between them, disrupting the network of associations that conventionally organise their position in the world.

Constance Lytton's use of metaphorical juxtaposition where each image is kept distinct is paralleled in her assumption of the identity of Jane Warton. Having assumed the guise of the physically unattractive and awkward seamstress, Lytton's narrative of her subsequent experiences fluctuates repeatedly between 'I' and 'she': her underlying aristocratic identity and her working-class persona. Over recent years critics have offered a range of different theoretical frameworks for understanding and interpreting Lytton's often disconcerting shifts from first to third person, including inner psychological conflict, an impulse to self-harm, and reductive images of working-class identity. ${ }^{20}$ Importantly, the theoretical relation that Lytton is invoking is the entirely rational and egalitarian relation between actor and role, which Lytton deploys with characteristic exactness and imagination, informed by the contemporary practices of Edwardian feminist playwrights.

As Dan Rebellato has explained, 'Theatrical representation is metaphorical.,21 The actor's body does not actually become that of the role they perform, nor is there an illusion whereby the audience sees the actor's body as literally that of the character; rather the actor's body is metaphor for the character's. Some of the actor's physical attributes - appearance, gestures and so forth - become representative of those of the character, other attributes are recognised as irrelevant or contradictory, and are thus elided by the audience. It is this metaphorical relation that enables colour-blind and gender-blind casting, for example. The metaphorical relation between the actor's body and the body of the character performed is thus dynamic and can shift in the course of performance. Importantly, an actor's performance hinges on a dual awareness and command of the seen and the felt. The actor must be aware of

\footnotetext{
20 See e.g. Marie Mulvey-Roberts, 'Militancy, Masochism or Martyrdom? The public and private prisons of Constance Lytton', in Sandra Stanley Holton and June Purvis (eds), Votes for Women (Routledge: London, 2000), 170, 171; Michelle Myall, “"only be ye strong and very courageous”: the militant suffragism of lady constance lytton', Women's History Review 7:1 (1998), 61-84; Sue Thomas, "Scenes in the writing of 'Constance Lytton and Jane Warton, spinster': contextualising a cross-class dresser”, Women's History Review, 12:1 (2003), 60

${ }^{21}$ Dan Rebellato, 'When We Talk of Horses: Or, what do we see when we see a play?', Performance Research 14: 1 (2009), 25.
} 
the visual effect of her or his body on stage, the 'picture' the audience sees, while simultaneously persuading the audience to project feelings and thoughts into that character, to imagine an emotional landscape within the body they see on stage. Acting a role means imaginatively uniting the spectacular and embodied experience for both performer and audience.

Theatre also has the potential to marry spectacle and embodied feeling for the audience; it can invoke or recreate familiar images and scenes, including ones that formed the central iconography of the suffrage campaign, locating them within human dramas and encouraging the audience to empathise with the actors on stage, whose living bodies and expressed or projected feelings can give physical and immediate presence to the life and experience behind those images.

A host of novels, stories, articles and memoirs recounted the physical and mental agony of forced feeding - including two novels based on Constance Lytton's accounts of her experiences as Jane Warton: Gertrude Colmore’s Suffragette Sally and Constance Maud's No Surrender (1911) - but in spite of the integration of suffrage plays and performances into political meetings, and the popularity of plays and sketches about political conversion, physical violence against suffragettes was notably absent from their stages. ${ }^{22}$ Feminist and suffragist organisations such as the Actresses Franchise League and the Pioneer Players studiously avoided staging the physical degradation and torture of women. To stage the pain, personal invasion and degradation of forced feeding was to risk either disgusting an audience with an experience too disturbing and traumatic to be considered acceptable for public performance, or conversely to reduce women's suffering to mere entertainment or sensational thrills.

Not every playwright exercised the same scruples, however. Amongst hundreds of plays written in the course of the suffrage campaign, I have found only two that chose to dramatize force-feeding: The White Slave Traffic (1913) by A. Middleton-Myles and The Suffragette: or, A Woman's Vote (1914) by Marie Robson.

\footnotetext{
${ }^{22}$ Examples of suffrage plays about conversion include Elizabeth Robins's Votes for Women! (1907), Beatrice Harraden's Lady Geraldine’s Speech (1909), Gertrude Vaughan's The Woman with the Pack (1911), and Cicely Hamilton and Christopher St John's How the Vote was Won (1911). For posters depicting forced feeding see 'The Modern Inquisition' by Alfred Pearse, published by the WSPU in 1910, and, for the sensational and supposedly comic depiction of women's suffering, see 'The Prevention of Hunger Strikes' by R. F. Ruttley, and 'Feeding a Suffragette by Force', reproduced in Lisa Tickner, The Spectacle of Women: Imagery of the Suffrage Campaign (University of Chicago Press: Chicago, 1988), Figs.VII, 53 \& 54, p.109.
} 
Both plays clearly demonstrate the danger of reducing women's suffering to sensational spectacle bereft of the embodied experience so crucial to suffragist accounts of their shared ordeals. ${ }^{23}$

Marie Robson's The Suffragette was submitted to the Lord Chamberlain's Office for a public performance licence on 9 January 1914 for production at the Palace Theatre, Ryton-on-Tyne. The Reader of Plays in the censor's office, G. S. Street, scornfully but accurately described it as 'a mixture of suffragette polemics and old-fashioned melodrama'. ${ }^{24}$ The play was a re-working of Watts Phillips's popular seduction melodrama Lost in London (1867), with the topical twist that Kate Merton, the errant wife of an honest working man, does not abandon her husband and daughter through sexual temptation but is instead lured away by Cuthbert Vane's unscrupulous appeal to her political commitment and ambition - as Vane comments, 'quite a novelty, but very effective'. ${ }^{25}$ Kate then becomes a militant leader as well as Vane's mistress, and leads a band of suffragettes in setting fire to a hall, nearly killing her own daughter who has come to London in search of her. Kate's husband finally forgives her various sins, and she is happily reunited with her family.

The central plot of The Suffragette thus implies that militant suffragism is misguided and foolish, but the play also contains central scenes that cast a dark light on the government's treatment of female activists. One scene has Kate (under her suffragette pseudonym 'Mrs Sydenham') and her colleague Jessie, imprisoned and on hunger strike, being tempted with wine and chicken by prison warders in an effort to break their will. When they hold out, the doctor orders Kate to be dragged to a chair and bound:

Mrs S. screams and resists as much as possible - they adjust forcible feeder into her mouth and administer food

SERG[EANT]. I hate these jobs. I can't bear to see a woman treated like this. DOC[TOR]. It's their own fault, they give us no choice we can't have them die on our hands.

\footnotetext{
${ }^{23}$ For the role of narratives of force feeding in building a sense of suffrage community, see Laura E. Nym Mayhall, 'Creating the “Suffragette Spirit”: British Feminism and the historical imagination', Women's History Review 4:3 (1995).

${ }^{24}$ Letter from G. S. Street to Lord Chamberlain’s Office, 9 January 1914, accompanying Marie Robson, The Suffragette: or, A Woman's Vote, British Library, Lord Chamberlain’s Plays (LCP) $1914 / 3$.

25 Robson, Suffragette, I, 45..
} 
etc. Segt. releases her, insisting she is exhausted. Jess is also force-fed, making her mouth bleed. Doctor is unbothered. Mrs S. bathes her face \& brings her round. ${ }^{26}$

Though the women's ordeal is brought to a comic close when Jessie's sweetheart rescues them, feeding them fish and chips before springing them from prison, the scene was sufficiently politically uncomfortable for the censor's Reader, George Street, to recommend that it be cut in its entirety for being 'as a whole, a libel (I hope) on police methods', ruling that 'the passage is clearly inadmissible' despite the playwright's direction that 'this business must be done as delicately as possible, mostly hidden from audience'. ${ }^{27}$ Though the play was recommended for a licence once these scenes had been excised, it is unclear whether it was ever performed, as no record of performance has been found.

Where Robson’s 'very dubious’ suffrage polemics were deemed unacceptable, the Lord Chamberlain's Office did grant a licence to far cruder and more sensational representations of force-feeding in Middleton-Myles's The White Slave Traffic - a play with no suffragist content or concerns. ${ }^{28}$ Another Reader of Plays, Charles Brookfield, described it in his report as 'an artless, conventional, meandering melodrama of the "Woman and Wine" type. Not much about the "White Slave Traffic" - beyond an occasional speech - to justify the title - should think this is an old title altered to suit the times. ${ }^{29}$ The white slave element of the play's convoluted plot involves actress Stella Vincent being tricked into a false marriage to Ramon, who takes her to South America and then attempts to force her into prostitution. When Stella resists, Ramon and his accomplice Cara have Stella tied up and strung from the ceiling. In the face of Stella's determination, Ramon contemplates further measures:

RAMON: We can't tempt her to eat we must try forceable feeding. That is a charming punishment copied from the English, it has the merit of hurting the patient and at the same time, it is an act of kindness on the part of those who do the hurting. (II, iv, 19)

In the next scene Cara and the other prostitutes taunt Stella with champagne and food, then use a pump to force-feed her, as Cara comments sardonically, 'If it's good

\footnotetext{
${ }^{26}$ Ibid, II, iii, 40-43.

${ }^{27}$ Ibid, Letter from G. S. Street to Lord Chamberlain’s Office, 9 January 1914.

${ }^{28}$ Ibid.

${ }^{29}$ Report by Charles Brookfield, 11 March 1913 on A. Middleton-Myles, The White Slave Traffic BL LCP 1913/10. Licensed to Forester's Theatre, 15 March 1914.
} 
enough for the respectable women in England, sanctioned by the law of the most chivalrous and Christian country, it can’t be too bad for such as you!' (II, v, 21-2) When a former sweetheart rescues Stella, he ties Cara up her stead, and the procuress is then beaten by Ramon before he notices the substitution. The play was blithely recommended for licence by Brookfield, who commented simply that, 'I think it is a pity that managers should try to make capital out of such themes and titles as "The White Slave Traffic", but it is a question of taste rather than morals.' 30

These plays and the censors' responses to them make clear why suffragist playwrights were wary of staging the trials of force-feeding and thereby risking its reduction to titillating spectacle. Both plays are clearly cynical about the government's description of force-feeding as 'medical treatment', framing it quite clearly as torture. The unproblematic granting of a licence to The White Slave Traffic compared to the cuts required of The Suffragette is perhaps surprising, given the former’s more direct criticism of government hypocrisy, but Middleton-Myles’s melodrama invites little interest in Stella's subjective experience of force-feeding; the innocent Stella is neatly swapped with her persecutor, so that audience members who prefer their torture flavoured with poetic justice can enjoy it more fully. The Suffragette, by contrast, frames the force-feeding incident with a long and intimate scene in which Kate and Jessie discuss the pain of hunger-striking and are sorely tempted by the food offered to them. Such a close focus on the women's inner feelings invites the audience to imagine the physical experience of self-starvation, a sympathetic intimacy potentially extended into the subsequent scene of force-feeding, especially where action is not directly visible to the audience but left to their imagination, as the playwright directs. Stella's whipping and force-feeding invokes no such felt reality: the audience is invited to gaze, not to feel with her; this is spectacle alone. Notably, when force-feeding was reduced to cheap spectacle, the censor's office was ready to licence it, but when audiences were encouraged to feel with the suffragettes and imagine the realities of the government's 'special medical treatment', it was deemed unfit for the public stage.

The relation between the fictional world of dramatic action, the audience’s sympathetic and conscious positioning, and the on-stage reality of the actors' bodies was a crucial element of early twentieth-century feminist and suffrage drama.

\footnotetext{
30 Ibid.
} 
Understanding the sophisticated and dynamic deployment of this relation by suffrage playwrights is key to appreciating Constance Lytton's theoretical framework and narrative strategies. Actresses’ bodies were a valuable asset in the suffrage campaign: prominently placed under the banner of the Actresses’ Franchise League in processions, demonstrations and meetings, they combined professional status, training and discipline with a degree of glamour and a history of public visibility. A number of playwrights drew on this same dynamic to stage meta-theatrical moments of selfconscious celebration. In Christopher St John's The First Actress (1911), for example, an all-star cast of actresses, including Decima Moore, Lillian Braithwaite and Ellen Terry, played their professional predecessors from the seventeenth century onwards. The performance did not sink the actresses' famous identities in their roles but showcased them as living successors to the first woman who challenged the male monopoly of the stage. Similarly, in a 1909 performance of Cicely Hamilton's A Pageant of Great Women the celebration of famous women through history included Ellen Terry's appearance as beloved actress Nance Oldfield. With meta-theatrical resonance, Terry declared that, if male Prejudice had his way, 'The stage would be as dull as now 'tis merry, / No Oldfield, Woffington, or - Ellen Terry!' 31

Even devoid of celebrity status, the relation between the living body of the professional woman on stage and the role she performed could be deployed to underline the physical realities of women's lives. One of the most popular suffrage dramas, Evelyn Glover's A Chat with Mrs Chicky (1912), drew on this dual bodily presence. In the comic sketch an anti-suffragist, Mrs Houlbrook, tries to persuade her brother's charwoman, Mrs Chicky, to sign her petition opposing the vote. Mrs Chicky continues to work throughout Mrs Houlbrook's disquisition on women's weakness, washing and scouring the hearth, folding dustsheets, and sweeping the floor around the seated lady. Both Mrs Chicky’s words and actions offer a counter-argument to the anti-suffragists' arguments:

MRS HOULBROOK: Can't you see that the right to vote really depends on physical force - strength, you know - and that women haven't got that? (MRS CHICKY finding MRS HOULBROOK in her way gets up and pushes her, chair and all, a foot or so centre with perfect ease.) ${ }^{32}$

\footnotetext{
31 Cicely Hamilton, A Pageant of Great Women (Suffrage Shop: London, 1910), 31.

${ }^{32}$ Evelyn Glover, A Chat with Mrs Chicky, in Linda Fitzsimmons and Viv Gardner (eds.), New Woman Plays (Methuen: London, 1991), 110.
} 
The display of strength is crucially both the actress's and the character's: their bodies' actions and attributes merge in the on-stage action to make apparent the physical reality that anti-suffragists denied.

Feminist and suffragist Cicely Hamilton exploited this real-life dynamic of women's bodies on stage to discomfort the audience of her popular hit Diana of Dobson's (1908). The play opens with undernourished and overworked shop-girls undressing for bed in the store's living-in dormitory. In a deliberately de-eroticised striptease, the women take off the accoutrements - false hair, ribbons, collars and corsets - that construct their shop-floor glamour, revealing the undernourished and overworked bodies that lie beneath. The actresses’ own bodies are revealed to the watching audience, but not within a conventional frame of sexual titillation and entertainment. The response of contemporary reviewers suggests thwarted expectations: the Pall Mall Gazette warned hopeful ticket-buyers that nothing more was revealed than 'a gleaming shoulder - a pink vest - a peering foot'; and the Stage condemned the scene as 'wanting in taste' while noting, with an unmistakable tinge of disappointment, that 'these different stages of undress do not happen to be made pretty'. ${ }^{33}$ The actresses' bodies were not necessarily as overworked and poorly fed as the shop-workers they played, - though given the long hours, low rates of pay, and uncertain employment of most female performers, they could well have been - but the spectacle of their undressed bodies disconcertingly located the audience as themselves consumers of women's bodies, whether on stage or behind the counter. ${ }^{34}$

This is the dynamic on which Constance Lytton drew in her account of her masquerade and imprisonment. Carefully costuming herself for her role as Jane Warton, Lytton rendered herself deliberately ugly, complete with unbecoming haircut, cheap, ill-fitting clothes and an array of WSPU badges - an appearance so deliberately absurd that some critics have seen her as inherently unreal: Caroline Howlett has asked whether Lytton's transformation should be seen as a form of female-female impersonation, one woman burlesquing another kind of woman for failing to get femininity right; and Barbara Green has interpreted Jane Warton as an embodiment of the anti-suffragists' fears of disruptive femininity, a parody of a parody of the

\footnotetext{
${ }^{33}$ Pall Mall Gazette (13 Feb 1908); Stage (13 Feb 1908), reproduced in Cicely Hamilton, Diana of Dobson's, ed. Diane F. Gillespie and Doryjane Birrer (Broadview: Peterborough, Ontario, 2003), 173, 171.

${ }^{34}$ See Tracy C. Davis, Actresses as Working Women: Their Social Identity in Victorian Culture (London and New York: Routledge, 1991) for details of actresses’ working conditions and rates of pay.
} 
suffragette, not an individual woman but a representation of a disruptive community. ${ }^{35}$ Yet, as Lytton herself explains, the moniker 'Jane Warton’ derived from a combination of Joan of Arc and a compression of the surname of a distant but sympathetic relative named 'Warburton' - implying a degree of personal investment and respect, however carefully she constructed an unattractive and undignified appearance to hide her identity and demonstrate the unequal treatment meted out to women unprotected by prettiness. ${ }^{36}$

Lytton's narrative fluctuates repeatedly and rapidly between first-person and third-person narration of Jane's experiences. So, for example, Lytton locates a store that is perfectly suited to buying a hat and trimmings for the seamstress: 'Finally she succeeded in getting the right one of stitched cloth, with a plait of cloth around the crown. Before leaving Manchester I realised that my ugly disguise was a success. I was an object of the greatest derision to street-boys, and shop-girls could hardly keep their countenances while serving me.' (241) Lytton holds herself separate from her role while constructing her disguise, but as actress she experiences her spectators' jeering laughter directly. Similarly, Lytton describes her appearance at the police station after her arrest:

It was the turn of Jane Warton. She walked across to the policeman, one shoulder hitched slightly above the other, her hair sticking out straight behind and worn in slick bandeaus on either side of her face, her hat trailing in a melancholy way on her head. The large, grey woollen gloves were drawn up over the too short sleeves of her coat; on the collar of it were worn portraits of Mrs. Pankhurst, Mrs. Lawrence and Christabel, in small china brooches; her hat had a bit of tape with 'Votes for Women' written on it, interlaced with the cloth plait that went round it, and eye-glasses were fixed on her nose. Her standing out in the room was the signal for a convulsed titter from the other prisoners. 'It's a shame to laugh at one of your fellow-prisoners,' said the policeman behind the desk, and the tittering was hushed. It was all I could do not to laugh, and I thought to myself "Is the Punch version of a Suffragette overdone?" As I got back to my companions they too were laughing, but I thought it wonderfully kind of the policeman to have spoken on my behalf. (249)

\footnotetext{
35 Howlett, 'Writing on the Body?’, 33-4; Barbara Green, Spectacular Confessions: Autobiography, Performative Activism, and the Sites of Suffrage 1905-1938 (Macmillan: Basingstoke, 1997), 86-7.

36 See Prisons and Prisoners, 237-8. On symbolism of Joan of Arc, see Rosemary Betterton, Intimate Distance, 52.
} 
The shift to first person again marks a moment when the laughter may be aimed at the role of a deliberately awkward and ungainly woman but it is also experienced in real time by the actress playing her.

The most striking and oft-quoted incidence of narrative fluctuation between first and third person is Lytton’s first traumatic experience of force-feeding:

Then the food was poured in quickly; it made me sick a few seconds after it was down and the action of the sickness made my body and legs double up, but the wardresses instantly pressed back my head and the doctor leant on my knees. The horror of it was more than I can describe. I was sick over the doctor and wardresses, and it seemed a long time before they took the tube out. As the doctor left he gave me a slap on the cheek, not violently, but, as it were, to express his contemptuous disapproval, and he seemed to take for granted that my distress was assumed. At first it seemed such an utterly contemptible thing to have done that I could only laugh in my mind. Then suddenly I saw Jane Warton lying before me, and it seemed as if I were outside of her. She was the most despised, ignorant and helpless prisoner that I had seen. When she had served her time and was out of the prison, no one would believe anything she said, and the doctor when he had fed her by force and tortured her body, struck her on the cheek to show how he despised her! That was Jane Warton, and I had come to help her. (269-70)

The split between 'Jane' and ' $\mathrm{I}$ ' in this passage has been interpreted in a wealth of different ways by critics over the last fifteen years. Barbara Green and Jason Haslam both see in Lytton's careful movement between first and third person a complex negotiation between individual and group identity, between her own personal voice and membership of the wider collective of the suffrage movement and its public profile. ${ }^{37}$ A number of other critics have significantly analysed the shift from first to third person as evidence of a psychological split in Lytton herself, interpreting her actions as a form of masochism and self-torture in arguments that echo anti-suffragist accusations of hysteria. Caroline Howlett has argued that in her external view of Jane Warton, Lytton necessarily takes up the subject position of doctors and wardresses, the only people privy to the spectacle of force-feeding, so that Lytton's narration becomes a form of self-torture. ${ }^{38}$ Marie Mulvey-Roberts describes the dynamics of Lytton's disguise as a 'fission of self . . . enacted through a psycho-drama of a poor

\footnotetext{
${ }^{37}$ Barbara Green, Spectacular Confessions: Autobiography, Performative Activism, and the Sites of Suffrage 1905-1938 (Macmillan: Basingstoke, 1997), chap. 1; Jason Haslam, 'Being Jane Warton: Lady Constance Lytton and the Disruption of Privilege’, in Captivating Subjects: Writing, Confinement, Citizenship, and Nationhood in the Nineteenth Century, ed. Jason Haslam and Julia M. Wright (Univ. of Toronto Press: Toronto, 2005), 48.

38 Howlett, 'Writing on the Body?', 32.
} 
woman denying food to her rich counterpart', a self-martyrdom designed to achieve suffragette canonisation. ${ }^{39}$ Sue Thomas instead interprets the divergence of perspective and body as a split between the 'transcendent spirit' of the upper-class woman and the suffering body of the working woman - an interpretation that implies an inherently patronising and superior subject-position on Lytton's part - in contradistinction from the repeated analogies and parallels that Lytton provides between dependent spinsters like herself and the abject and despised women of the third division in prison. ${ }^{40}$ In fact, the clearest and most direct framework for understanding Lytton's move from first to third person in describing her force-feeding and the subsequent slap from the doctor is that of actor and role - a metaphorical and literal relation that precisely describes her position, and that forms part of her wider challenge to the systems and judgements that circumscribe and constrain Constance, Lytton, Jane Warton and other 'superfluous' spinsters and neglected workers. Just as the celebrated actress (and suffragist) Mrs Patrick Campbell described her determination to win audience sympathy for her role as Paula Tanqueray, a reformed kept-woman in Pinero's The Second Mrs Tanqueray (1893), as a resolve to 'plead for Paula', so Lytton was fighting for a recognition of the suffering and right to respect of Jane Warton. ${ }^{41}$

While performing the role of Jane Warton, Constance Lytton undergoes precisely the same physical experience as her character does: the pain, nausea and sense of suffocation are the same. The doctor's slap is similarly physically experienced by the actor, but the emotional reality that underpins it is significantly different for actor and role: the doctor's expression of contempt is exclusive to the working woman, whose powerlessness is intrinsic to her political and social position. Lytton's abrupt Brechtian distinction between actor and role acknowledges this distance between her own privileged position and the socially and personally distinct

\footnotetext{
${ }^{39}$ Marie Mulvey-Roberts, 'Militancy, Masochism or Martyrdom? The public and private prisons of Constance Lytton’, in Sandra Stanley Holton and June Purvis (eds), Votes for Women (Routledge: London, 2000), 170, 171. Michelle Myall similarly ascribes psychological rather than political motives for Lytton’s own actions, see e.g Michelle Myall, “"only be ye strong and very courageous”: the militant suffragism of lady constance lytton', Women's History Review 7:1 (1998), 61-84, thereby perpetuating anti-suffragists' diagnosis of female hysteria behind the characterisation of suffragettes' endurance of physical assault, imprisonment and forced-feeding as 'mock martyrdom', unnecessary suffering sought through motives of masochism or self-publicity.

${ }^{40}$ Sue Thomas, "Scenes in the writing of 'Constance Lytton and Jane Warton, spinster': contextualising a cross-class dresser”, Women's History Review, 12:1 (2003), 60.

41 Mrs Patrick Campbell, My Life and Some Letters (Hutchinson: London, 1922), 70.
} 
experience of a woman upon whose vulnerability the doctor's dismissive slap is premised.

Constance Lytton's narrative of forcible feeding in the persona of Jane Warton also bears clear resemblances to American writer Djuna Barnes’s piece ‘How It Feels To Be Forcibly Fed', published several months later in the New York World in September 1914. Writing as a stunt reporter, Barnes voluntarily undertook to be force fed in order to give a first-person account of what hundreds of British suffragettes were enduring at the hands of their government. Barnes frames her experience as play-acting, with significantly less at stake for her than for British prisoners: 'For me it was an experiment. It was only tragic in my imagination. ${ }^{42}$ Wrapped tightly in a form of winding sheet like a corpse and held down by three doctors, Barnes experienced a level of disempowerment and overwhelming pain that cut through any notion of performance, pretence or inauthenticity:

He had inserted the red tubing, with the funnel at the end, through my nose into the passages of the throat. It is utterly impossible to describe the anguish of it.

The hands above my head tightened into a vise, and like answering vises the hands at my hips and those at my feet grew rigid and secure. Unbidden visions of remote horrors danced madly through my mind. There arose the hideous thought of being gripped in the tentacles of some monster devil fish in the depths of a tropic sea, as the liquid slowly sensed its way along innumerable endless passages that seemed to traverse my nose, my ears, the inner interstices of my throbbing head. Unsuspected nerves thrilled pain tidings that racked the area of my face and bosom. They seared along my spine. They set my heart at catapultic plunging. $[\ldots]$

Still the liquid trickled irresistibly down the tubing into my throat; every drop seemed a quart, and every quart slid over and down into space. I had lapsed into a physical mechanism without power to oppose or resent the outrage to my will. ${ }^{43}$

As Barbara Green has noted, Barnes offers herself as spectacle - and the article is illustrated by numerous photographs of her ordeal - but her article describes her feelings not what she can see, as the reporter herself is held fixed, her vision blinded by the doctor's light; Barnes thereby questions the degree of female agency or control

\footnotetext{
42 Djuna Barnes, 'How It Feels To Be Forcibly Fed’, New York World Magazine, 6 Sept 1914, 5.

43 Ibid.
} 
inherent in a woman thus rendering herself a spectacle while her own specularity is severely curtailed. ${ }^{44}$ But, for all Barnes’s introduction of her experience as inauthentic and performed, her actual sensations are all too real and immediate, erasing her individuality and reducing her to an outraged and agonised body. Her physiological and psychological responses cut through any notion of play-acting as she is overwhelmed by pain so intense it poses a threat to her sense of self.

As Jean Marie Lutes has noted, Barnes goes beyond the usual paradigm of stunt reporters observing medical experts, juxtaposing the truth of their physical sensations with the disinterested perspective of professionals: 'Barnes ... goes beyond this paradigm, describing the invasion of her mind and body with an intensity of detail that takes the narrative out of the confines of doctor-patient, expert-layperson conflict into a crisis of existential proportions. ${ }^{45}$ Like Constance Lytton, Djuna Barnes acknowledges the difference in choice and power between herself and women whose experience she has sought to reproduce in her voluntary experiment:

There it is -- the outraged will. If I, playacting, felt my being burning with revolt at this brutal usurpation of my own functions, how they who actually suffered the ordeal in its acutest horror must have flamed at the violation of the sanctuaries of their spirits. ${ }^{46}$

Barnes's ordeal reveals a core of experiential truth: the overwhelmingly painful and obliterating nature of being force-fed. The male doctor who continues to believe that what has taken place has been mere performance is the one who appears superficial and disconnected, unaware of the reality of what has just taken place:

It was over. I stood up, swaying in the returning light; I had shared the greatest experience of the bravest of my sex. The torture and outrage of it burned in my mind; a dull, shapeless, wordless anger arose to my lips, but I only smiled. The doctor had removed the towel about his face. The little, red mustache upon his upper lip was drawn out in a line of pleasant understanding. He had forgotten all but the play. ${ }^{47}$

Barnes is initiated into an urgent reality that includes the revelation of her psychic vulnerability and the contingency of her identity. ${ }^{48}$ The doctor, unaware of the truth

\footnotetext{
44 Green, Spectacular Confessions, 175-83.

45 Jean Marie Lutes, Front Page Girls: Women Journalists in American Culture and Fiction, 180-1930 (Cornell University Press: Ithaca and London, 2006), 154.

46 Barnes, 'How It Feels'.

47 Ibid.

48 In a strikingly similar experiment, on 15 June 2013 the human rights organization Reprieve recruited rapper and actor Yasiin Bey (aka Mos Def) to submit his body and fame to force-feeding in
} 
revealed through her role-playing, remains superficial and insubstantial, part of the surrounding show, despite his complacent sense of superior knowledge and authority.

Similarly, Constance Lytton's narration of her force-feeding in the persona of Jane Warton cuts through to the essential obliterating experience of pain, nausea and helplessness. There is nothing inauthentic or performative about her sensations. Performance in the sense of inauthenticity - an outward show whose inner reality or true identity is concealed - applies rather to the structures that surround those moments of agony and the body's involuntary responses. It is the authorities' supposed justice, objectivity, fairness and duty of care that are revealed as outward show, lacking substance; the force-feeding of Jane Warton reveals the reality behind the assumed postures of government, prison authorities and doctors. Theirs, not hers, are the inauthentic performances.

A further network of meanings and associations is evoked in Lytton's narration of the doctor's contemptuous slap through its similarity to an earlier episode in Prisons and Prisoners. In an isolated and seemingly random detail in the book's opening account of her conversion from suffragist to suffragette, Lytton recalls, when she was visiting the town of Littlehampton, seeing an elderly and misshapen sheep break from its incompetent keepers' hands on the way to the slaughterhouse. Amidst a jeering crowd, the inept gaolers recapture the animal and 'as they carried it away one of them, resenting its struggles, gave it a great cuff in the face.' (13) Lytton reproved the men for doing their job badly, not just taking the sheep to be killed but hurting and insulting it as well, and they slunk off ashamed. Lytton then muses on the distance between the decrepit sheep and the vigour it would have possessed if it had been allowed to lead a natural life on the mountainside. She then explicitly likens this to

order to campaign against the use of force-feeding at Guantanamo Bay and its designation as medical treatment. As Ben Ferguson recounts, 'There was no rehearsal: after all, no acting would be required. He swapped his black leather jacket, jeans and designer shoes for an orange jumpsuit. In an instant, he was no longer Mos Def - rapper and Hollywood star - but a powerless prisoner.'

https:/www.theguardian.com/world/shortcuts/2013/jul/09/yasiin-bey-force-fed-guantanomo-bay-mosdef - accessed 25 September 2017. Bey is in increasing pain as the nasal tube is inserted, and it is withdrawn and prepared for reinsertion. At this point Bey repeatedly begs 'No, stop, please, stop', but those performing the procedure continue to restrain him, until he says 'It's me. Please stop. I can’t do it.' - at which point they call a halt and release him. Though Bey is not performing a character or taking part in any form of pretence, the default framework for the participants' understanding of one body standing in for other less powerful bodies is thus clearly that of actor and role. It is only when those performing the procedure abandon their assumption that Bey is play-acting and realise his genuine distress that they abandon the experiment.

See https://www.theguardian.com/world/video/2013/jul/08/mos-def-force-fed-guantanamo-bay-video for Asif Kapadia's video of the event. 
the position of women throughout the world denied human dignity and justice. Thus, in narrating her experiences as Jane Warton, Lytton once again superimposes and juxtaposes two images - the doctor slapping working-class Jane Warton and the shepherd cruelly cuffing the bedraggled sheep. The prison doctor is implicitly paralleled with an incompetent farmhand, taking out his frustration on a helpless animal - a correspondence that further suggests that he sees the lower-class woman as having no more power or recourse than a sheep on its way to slaughter. The echo of the earlier episode also implies that Jane Warton in all her awkwardness and impoverishment is an example of the distorting and cramping effects of social injustice and exploitation. The associations reverberate still further in Lytton's emphasis on the cramped and deformed lives of women like herself, the superfluous spinsters of the upper classes, whom she refers to as 'the blind, the lamed, the maimed and the dumb', who can claim no reverence or pity in their willing submission to 'the yoke'. (41) Lytton thus includes herself in the metaphor of woman as abused animal. Though the prison doctor would never knowingly slap this aristocratic inmate, not only does Lytton's body receive the blow but her confined life is similarly limited and distorted from its natural potential by the callous power system of which the prison doctor's slap is just one particularly legible expression. The bodies of Jane Warton, Constance Lytton and the prison doctor are thus doubled and tripled, unsettling established hierarchies of power and social order, leaving the implications unfixed but resonating in an intricate pattern of power abused and potential wasted.

The core reality of Constance Lytton's / Jane Warton's physical pain is immediate and visceral, while the two identities split at the moment when Lytton's mind returns to a consciousness of her ability to speak publicly and be heard. At that point the power structures that dictate the social status and value of the aristocrat and the seamstress split them apart. As woman and doctor further merge with farmhand and sheep, so the hierarchies that hold their social identities so widely separate are challenged and destabilised. Lytton's empathy is clear and precise, as is her precision about what she has experienced. It is the social structures, class and gender hierarchies that surround the force-fed woman and her doctor that are destabilised. Through a combination of visual metaphors and the precise relation of actor and role, Lytton uses performance to convey the visceral reality of her sensations and the comparative unreality, the asserted and performative nature of the surrounding systems of justice, government and social class that sought to deny that experience, 
rendering women's identity - especially poor and powerless women - contingent and precarious. After her release, Lytton spoke publicly of her differential treatment as Jane Warton. The Home Secretary Herbert Gladstone issued a statement contradicting Constance Lytton's version of events: she had denied permission for her heart to be examined on admission as Jane Warton, and her heart had been thoroughly tested and found to be healthy before she was force fed; it was only her violent resistance to force feeding that had produced a risk to her health and led to her release ${ }^{49}$ Her brother, Lord Lytton, asked questions in the House of Lords, and protested when an enquiry was denied and prison officials' assertions accepted without question. ${ }^{50}$ The government's performance of objective justice played on, attempting to ignore one woman's masquerade and the disruptive truths it revealed.

A year later, having spoken publicly on her experiences as Jane Warton and seen questions raised in Parliament on the unequal treatment of suffragette prisoners, Lytton was once again arrested in a deputation and brought before a magistrate. When the prosecutor totalled up her record of stone throwing and imprisonment, Lytton reminded him that he had left out the imprisonment of Jane Warton at Liverpool - to which the prosecutor testily replied 'Well, I'm very glad if I have.' (327) Rightly claiming Jane Warton's record as her own, Lytton's experiences in the role of working woman were not those of a working woman but stand in both metaphorical and literal relation to them. The intricate and experimental narrative techniques of Prisons and Prisoners married the visceral and the spectacular to convey both the physical immediacy and solid reality of her experiences, and the uncertainty and precarious multiplicity of female identity subject to the distorting powers of male authority.

\footnotetext{
49 Times, 10 Feb 1910, 10.

50 Times, 30 March 1910, 3.
} 